\title{
Szerkesztői előszó
}

„Egy kultúra, két kultúra, sok kultúra” - olvashatjuk e kötet egyik írásának élén. Bár a tanulmány szerzője a kanadai konföderációról értekezik, a címben jelzett dinamikus osztódás akár a teljes angol nyelvü kultúrára is érthető. Máris helyesbítenünk kell tehát: nem beszélhetünk ma már egyetlen angol nyelvü kultúráról, csakis az ilyen kultúrák sokféleségéről. Válogatásunk - amelynek írói között a magyarországi anglisztika jól ismert és elismert képviselői éppúgy helyet kaptak, mint a tehetséges pályakezdők - ebből a sokszínűségből kínál ízelítőt a legújabb irodalom- és kultúratudományi kutatások fényében.

A fönt idézett írás, T. Espák Gabriella tollából, nemcsak arra jó példa, hogy a társadalmi és politikai folyamatok milyen nagy mértékben meghatározzák az irodalom és a többi művészet müködését, hanem arra is, hogy manapság széles körben használt fogalmainknak milyen tanulságos történetük van. Kanada számára mind a mai napig alapvető elv a multikulturalizmus, arról pedig részletesen szól a cikk, hogy ennek értelmezése mennyi vitát váltott ki 1867-et követően (amely a kanadai történelemben is fontos fordulópont).

A kötet élén két olyan áttekintés áll, amely a kortárs magyarországi anglisztika legnagyobb vállalkozása számára készült. Évek óta dolgozik ugyanis egy sok szerzöből álló munkacsoport $A z$ angol irodalom magyar története munkacímü kiadványon, amelyben a szűkebb szakma a tágabb közvélemény és olvasóközönség elött szeretné megmutatni magát. Nemcsak azért fontos ez, mert a legutóbbi magyar nyelvü angol irodalomtörténet 1971-ben jelent meg, hanem azért is, mert pillanatfelvételt kíván adni arról, hogy a mai magyarországi anglisták miként gondolkodnak az irodalomról, a kultúráról és szakmájuk módszertanáról. Komáromy Zsolt és Reichmann Angelika írása egyúttal két különböző irányt is jelez. Az előbbi azt példázza, hogy a munkának számot kell vetnie a magyar kultúrában még mindig meglevő fehér foltokkal (Drydent nálunk alig-alig ismerik), egyszersmind újra kell gondolnunk a korábbi irodalomtörténetek által meghonosított korszak-kategóriákat. Az utóbbiban a 20. századi walesi irodalomról olvashatunk összefoglalót. Az ilyen áttekintésekre általában jellemző adatgazdagság mellett a szerző kitér a közösségi önmeghatározás kérdésére is, különösen arra, hogy ebben milyen szerepet játszik a nyelv, a történelmi múlt újraírása, valamint arra is, hogy milyen értelemben mondható Wales helyzete posztkoloniálisnak. Az identitásképzés egyébként is a kötet írásainak egyik visszatérő témája: a fönt már többször említett kanadisztikai cikk és Reichmann Angelika walesi témájú áttekintése mellett Szathmári Judit tanulmánya is az etnikai-kulturális önazonosság megalkotásának kérdését járja körül, a humor jelentőségét elemezve az 
amerikai indián közösségekben. Mint egyik forrását idézve írja: „ha egy nép képes magán nevetni [...], mindent túl fog élni”.

A komikum hasonlóan fontos Kérchy Anna eszmefuttatásában a nonszensz poétikájáról és politikájáról, de más összefüggésben: azt vizsgálja, hogy a nonszensz (amellett, hogy szórakoztat, nevetésre ingerel) hogyan válhat megismerésünk részévé, a valóság leképezésének milyen modelljeit hozza létre. Ehhez némileg hasonlóan a szöveg retorikai funkciójára összpontosít a kötet előző tanulmánya is, amelyben Csató Péter a jelentős hatású amerikai filozófus, Richard Rorty és a dekonstrukció viszonyát taglalja.

A további írások egy-egy müfajt vagy irodalmi szöveget vesznek górcső alá. D. Rácz István tanulmánya az elégia három változatát veszi számba az elmúlt évtizedek angol lírájából, rámutatva, hogy mindegyik beágyazódik a költészettörténeti hagyományba. Ezt négy regényelemzés követi. Vöő Gabriella Cormac McCarthy regényének elemzésében a káosz és a rend fogalompárját használja. A szerző (aki rámutat arra, hogy a szöveg nem realista regény) „a káoszelmélet atyjának”, Henri Poincarénak az elméletét mozgósítja értelmezéséhez, mely szerint a regénynek sikerül „ablakot nyitnia arra a dinamikus és holisztikus rendre, amely megnyilvánul a világegyetemben és életünkben". Pataki Éva arra keres választ, hogy Sunetra Gupta regényében a nagyvárosok (London, Párizs, Kalkutta) érzelmi légkörét hogyan alkotják meg az urbánus terek, valamint a lakók és a látogatók képzelete. Ugyancsak London a színtere Angela Carter Esték a cirkuszban címü regényének, amelynek városi tereiről és karaktereiről Schäffer Anett ír. A kötetet Fagyal József Szabolcs tanulmánya zárja, amely két regény elemzésén keresztül a kannibalizmus megjelenítését és funkcióját elemzi, kitekintve az angol és a világirodalom hagyományára is. Elemzése (mint a kötet többi írása) jól mutatja az irodalmi szövegek beágyazottságát és az írók állandó újító törekvéseit.

D. RÁcZ IsTvÁN 